\title{
Potential influence of the chemical composition of water on the stable oxygen isotope composition of continental ostracods
}

\author{
Laurent Decrouy • Torsten Walter Vennemann
}

Received: 30 July 2012/Accepted: 17 April 2013/Published online: 27 April 2013

(C) Springer Science+Business Media Dordrecht 2013

\begin{abstract}
Many studies in continental areas have successfully used the oxygen isotope composition of fossil ostracod valves to reconstruct past hydrological conditions associated with large changes in climate. Yet, ostracods are known to crystallise their valves out of isotopic equilibrium for oxygen and they generally have higher ${ }^{18} \mathrm{O}$ contents compared to inorganic calcite grown at equilibrium under the same conditions. A review of vital offsets determined for continental ostracods indicates that vital offsets might change from site to site, questioning a potential influence of environmental conditions on oxygen isotope fractionation in ostracods. Results from the literature suggest that $\mathrm{pH}$ has no influence on ostracod vital offset. A re-evaluation of results from $\mathrm{Li}$ and Liu (J Paleolimnol 43:111-120, 2010) suggests that salinity may influence oxygen isotope fractionation in ostracods, with lower vital offsets for higher salinities. Such a relationship was also observed for the vital offsets determined by Chivas et al. (The ostracodaapplications in quaternary research. American Geophysical Union, Washington, DC, 2002). Yet, when results of all studies are compiled, the correlation between vital offsets and salinity is low while the correlation between vital offsets and host water $\mathrm{Mg} / \mathrm{Ca}$
\end{abstract}

L. Decrouy $(\bowtie) \cdot T$. W. Vennemann

Faculty of Geoscience and Environment, Géopolis, Institute of Earth Science, University of Lausanne, 1015 Lausanne, Switzerland

e-mail: laurent.decrouy@unil.ch is higher, suggesting that ionic composition of water and/or relative abundance of major ions may also control oxygen isotope fractionation in ostracods. Lack of data on host water ionic composition for the different studies precludes more detailed examination at this stage. Further studies such as natural or laboratory cultures done under strictly controlled conditions are needed to better understand the potential influence of varying environmental conditions on oxygen isotope compositions of ostracod valves.

Keywords Ostracods - Oxygen isotope composition . Vital effect $\cdot$ Host water $\cdot$ Ionic composition

\section{Introduction}

In 1975, Fritz et al. measured for the first time the oxygen isotope composition of ostracod valves to infer late quaternary climatic trends. At this time, it was considered that ostracod calcite was near isotopic equilibrium with the oxygen isotope composition of host water (Dettman et al. 1995; Heaton et al. 1995). However, experimental cultures as well as analyses from natural environments revealed that the oxygen isotope composition of freshwater ostracod valves has a positive offset compared to the theoretical composition of an inorganic calcite grown under the same conditions (Xia et al. 1997; von Grafenstein et al. 1999). This vital offset is species-specific, not a 


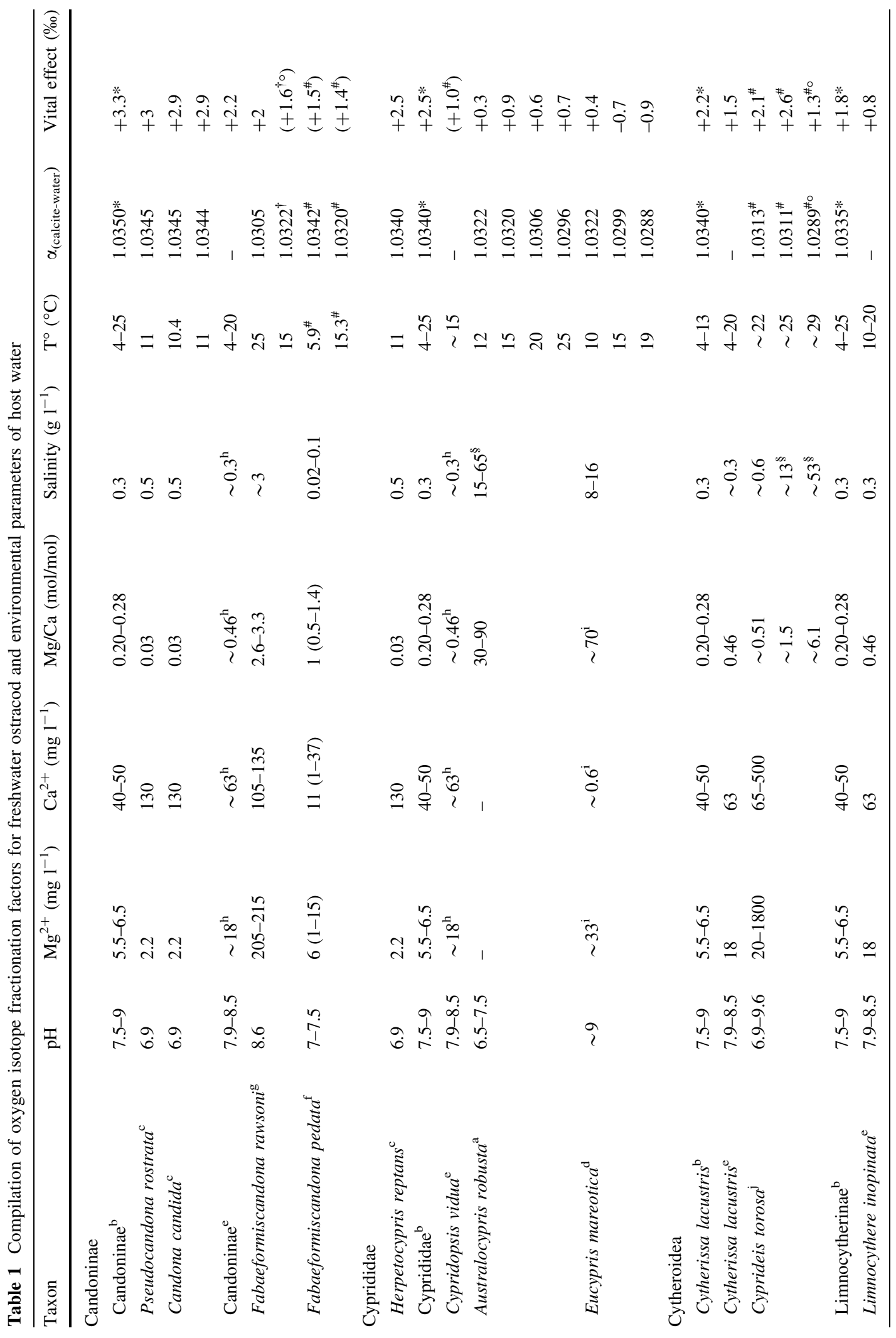




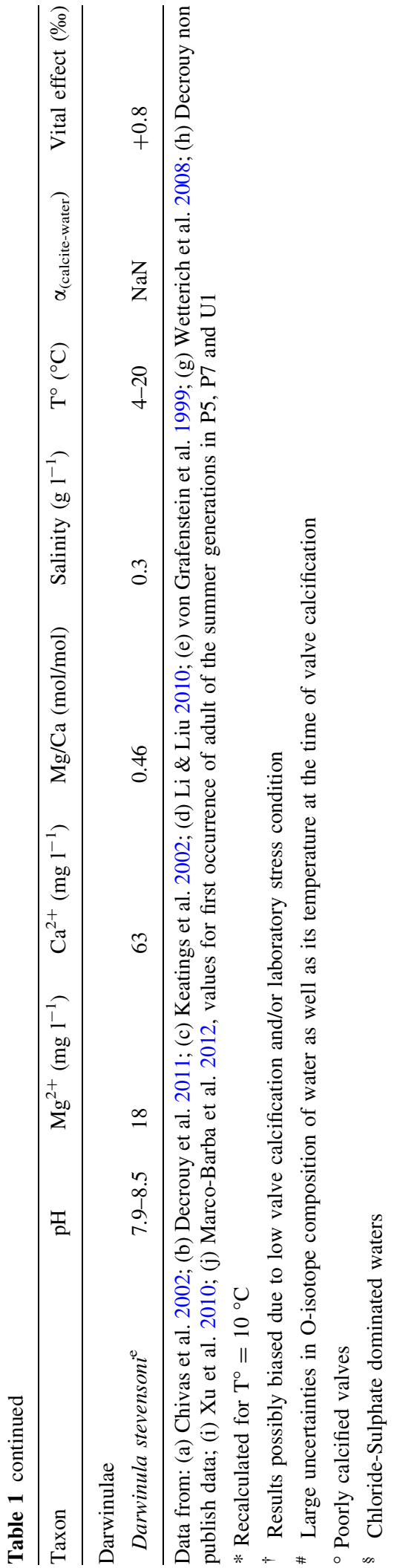

function of temperature, and has a range from a few tenths to several per mil. As vital offsets must be known to determine the oxygen isotope composition of water from that of the ostracod valves, much effort has been invested in assessing the vital offset of target species used for palaeoclimatologic reconstructions. Yet, when results from the literature are compiled, differences arise among vital offsets determined for a given species or a given taxonomic group, suggesting that vital offsets may vary from one location to the other and that environmental conditions may influence oxygen isotope fractionation during ostracod valve calcification. Data available from the literature are reevaluated to assess whether environmental conditions may affect oxygen isotope composition of ostracods or not.

\section{Re-evaluation of published data}

Table 1 presents the results of published studies on oxygen isotope fractionation in continental ostracods as well as the available information on host water. These results indicate that within a given family or subfamily, vital offsets vary from site to site, questioning whether environmental conditions influence the ostracod vital offset.

Keatings et al. (2002) suggested that vital offsets are not affected by $\mathrm{pH}$ of the host water. This is confirmed by a lack of correlation between vital offsets and $\mathrm{pH}$ in Table 2. Yet, variations of the isotopic composition of Cyprididae, Candoninae, and to a lesser degree Cytherideidae, are higher than analytical uncertainties and may be linked to real variations of environmental conditions rather than discrepancies due to analytical errors, differences due to the use of different fractionation factors (Friedman and O'Neil 1977; Kim and O’Neil 1997), or lack of knowledge of exact temperature or isotopic composition of water at the time of valve calcification.

Host water salinity versus oxygen isotopes vital offsets

On the basis of experimental cultures of Eucypris mareotica, Li and Liu (2010) suggested that a higher salinity of water might lower the magnitude of O-isotope fractionation between carbonate and 
Table 2 Pearson correlation coefficients for vital offsets and $\mathrm{pH}$, salinity, and $\mathrm{Mg} / \mathrm{Ca}$ of host water calculated for linear regressions and logarithmic regressions

\begin{tabular}{llll}
\hline & $\begin{array}{l}\text { pH-vital } \\
\text { offset } \\
\operatorname{linear} \log _{10}\end{array}$ & $\begin{array}{l}\text { Salinity-vital } \\
\text { offset linear/ } \\
\log _{10}\end{array}$ & $\begin{array}{l}\mathrm{Mg} / \mathrm{Ca}-\text { vital } \\
\text { offset linear/ } \\
\log _{10}\end{array}$ \\
\hline Candoninae $^{\mathrm{a}}$ & $0.29 / 0.29$ & $0.49 / 0.49$ & $\mathbf{0 . 5 7 / 0 . 5 3}$ \\
Cyprididae & $0.36 / 0.34$ & $0.05 / 0.30$ & $\mathbf{0 . 6 4} / 0.50$ \\
Cytherideidae & $0.00 / 0.00$ & $0.38 / 0.06$ & $\mathbf{0 . 4 3} / 0.22$ \\
All $^{\mathrm{a}}$ & $0.17 / 0.20$ & $0.41 / 0.53$ & $\mathbf{0 . 7 0} / 0.67$ \\
\hline
\end{tabular}

Values in bold indicate highest Pearson correlation coefficients

a Values for $F$. rawsoni cultured at $15{ }^{\circ} \mathrm{C}$ and for $F$. pedata were discarded from the calculation of $\mathrm{r}^{2}$ values (low calcification values and too large uncertainties on the determination of vital offset, respectively)

water during valve calcification. While salinity has not been measured during their experiments, the authors state: "The water used in the cultures was a mixture of lake water and deionized water to create different $\delta^{18} \mathrm{O}$ values. The salinity of water collected from Qinghai was about $16 \mathrm{~g} \mathrm{l}^{-1}$, and the maximum proportion of

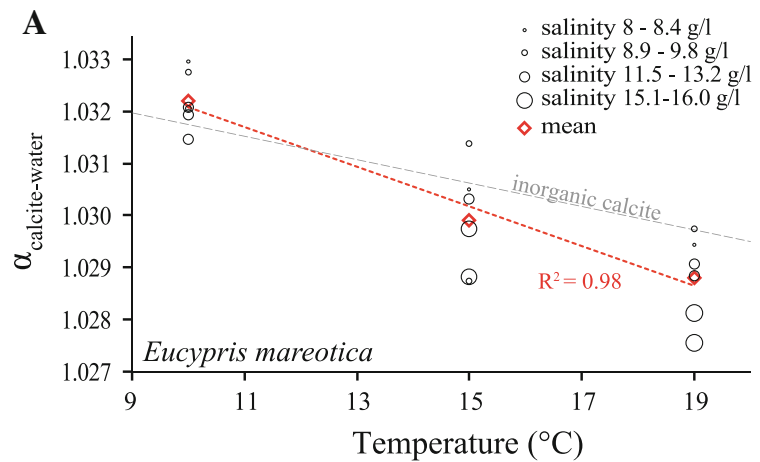

C

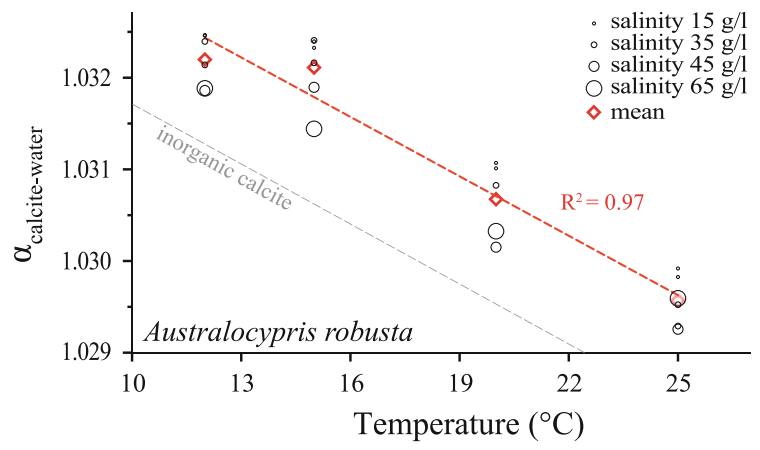

Fig. 1 Oxygen isotope fractionation factors $\left(\alpha_{\text {calcite-water }}\right)$ for $E$. mareotica relative to water temperature (a), oxygen isotope vital offsets $\left(\delta^{18} \mathrm{O}_{\mathrm{ostra}^{-}} \delta^{18} \mathrm{O}_{\text {calcite }}\right)$ for $E$. mareotica relative to estimated water salinity (b), oxygen isotope fractionation deionized water to lake water was less than $50 \%$ ". Hence, knowing the $\delta^{18} \mathrm{O}$ of each culture batch (Table 1 in $\mathrm{Li}$ and Liu 2010) and assuming that maximal and minimal $\delta^{18} \mathrm{O}$ values correspond to a salinity of water of 16 and $8 \mathrm{~g} \mathrm{l}^{-1}$, respectively, a simple mass balance calculation allows the salinity to be evaluated for each experimental batch. Figure 1a illustrates that the oxygen isotope fractionation factor $\left(\alpha_{\text {calcite-water }}\right)$ tends to decrease with increasing salinity. When vital offsets $\left(\delta^{18} \mathrm{O}_{\text {ostra }}-\delta^{18} \mathrm{O}_{\text {calcite }}\right.$, where the value for calcite is calculated to be in equilibrium with that of water) are plotted against water salinity, a negative linear relationship is obtained (Fig. 1b), suggesting that salinity influences the oxygen isotope composition of ostracods.

Although less pronounced, a similar relationship is observed in Fig. 1 c, d for Australocypris robusta cultured by Chivas et al. (2002). Concentration of calcium and water salinity of the solution from which carbonate is precipitated is also known to affect the oxygen isotope fractionation of inorganic calcite (Kim and O'Neil 1997; Li et al. 1997).

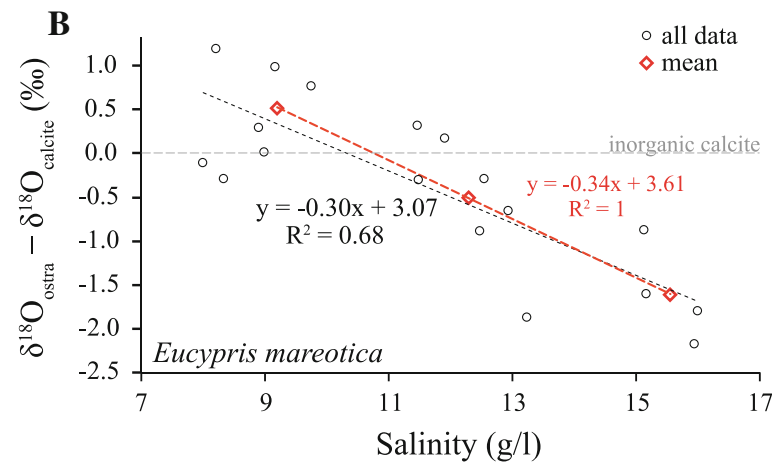

D

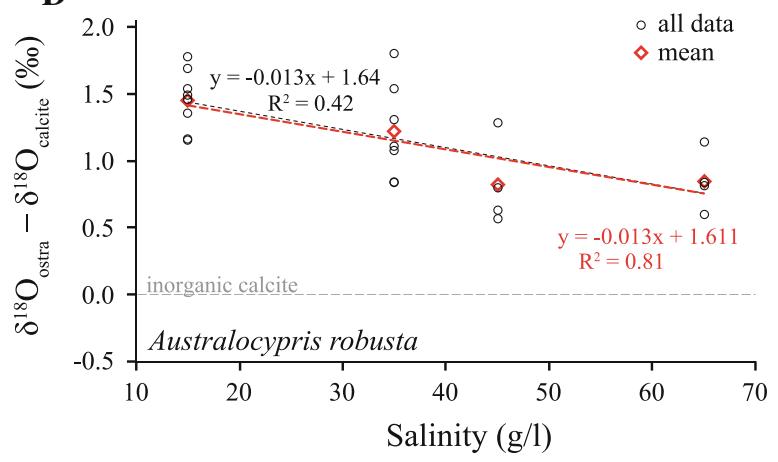

factors for A. robusta relative to water temperature (c), oxygen isotope vital offsets for $A$. robusta relative to water salinity (d), data for E. mareotica from Li and Liu (2010), data for A. robusta from Chivas et al. (2002) 

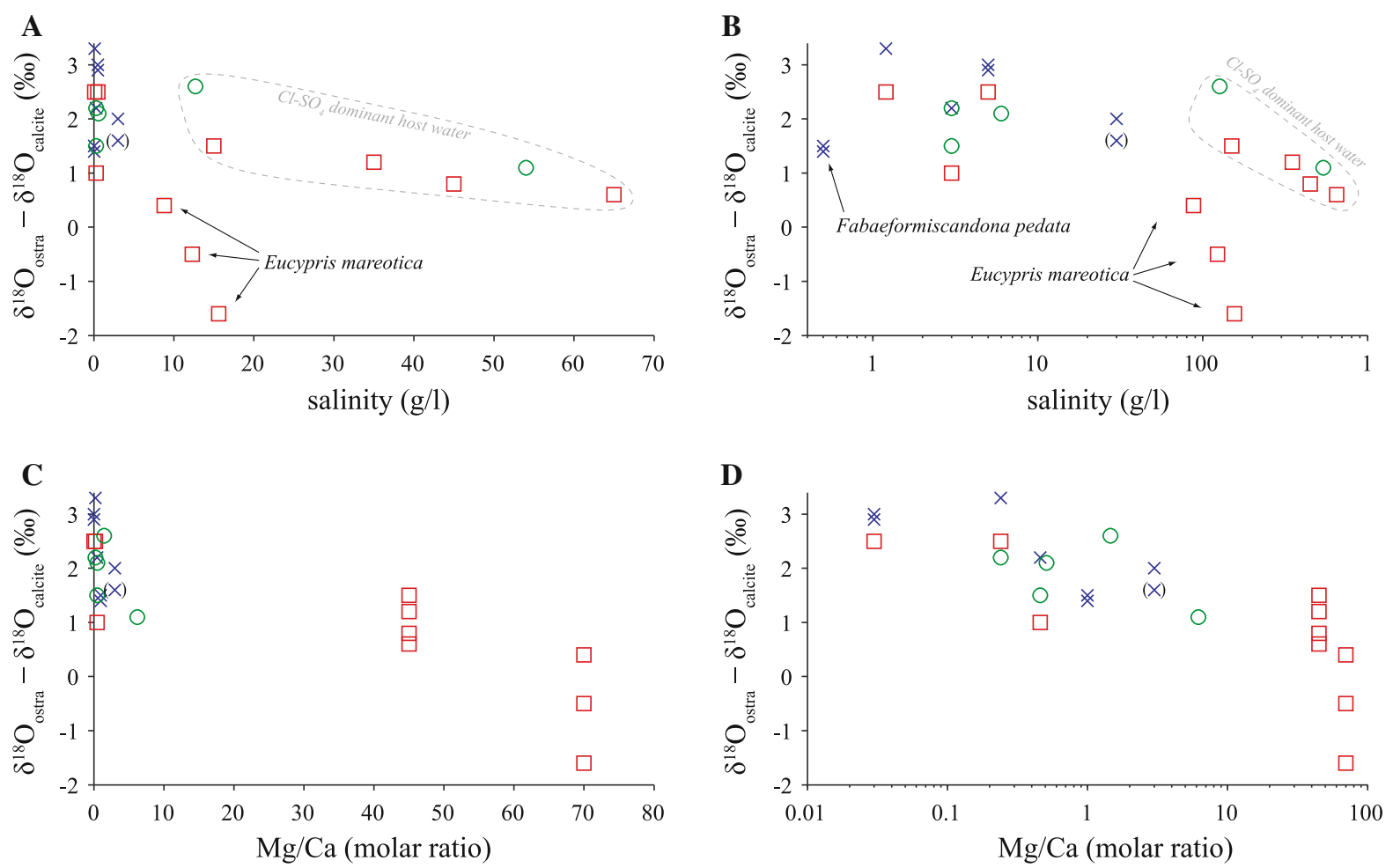

$\times$ Candoninae $\square$ Cyprididae $\bigcirc$ Cytherideidae

Fig. 2 Oxygen isotope vital offsets $\left(\delta^{18} \mathrm{O}_{\mathrm{ostra}}-\delta^{18} \mathrm{O}_{\text {calcite }}\right)$ for Candoninae, Cyprididae, and Cytherideidae against water salinity (a and b), vital offsets against $\mathrm{Mg} / \mathrm{Ca}$ molar ratio of water (c and $\mathbf{d}$ )

A recent study on the euryhaline water species Cyprideis torosa provides further support for an influence of the salinity of water on the oxygen isotope composition of ostracod valves (Marco-Barba et al. 2012). These authors noted that this species has different disequilibrium effects when calcifying in a stressful hydrochemical habitat and suggested that the higher incorporation of ${ }^{16} \mathrm{O}$ in the shell relative to stressed conditions at high TDS $\left(>20 \mathrm{~g} \mathrm{l}^{-1}\right)$ is due to lower valve calcification.

Ionic composition of host water versus oxygen isotope vital offsets

When all vital offsets for Cyprididae, Candoninae, and Cytherideidae are plotted against water salinity, the correlation is low (Fig. 2a, b; Table 2). In particular, the values for $E$. mareotica fall below the observed overall logarithmic decrease. Thus, other parameters may also affect ostracod vital offsets. Unfortunately, except molar ratios for magnesium-calcium $(\mathrm{Mg} / \mathrm{Ca})$, chemical composition of water is not available for the complete range of species studied. When vital offsets are plotted against water $\mathrm{Mg} / \mathrm{Ca}$, a better correlation is obtained (Fig. 2c, d; Table 2), suggesting that the ionic composition of water may be the key factor. In fact, only mean values are available for each study. The correlation might, therefore, be higher if $\mathrm{Mg} / \mathrm{Ca}$ had been measured during each single experiment. The magnesium concentration of the solution precipitating the carbonate is known to affect calcite growth (Davis et al. 2000) as well as the oxygen isotope composition of carbonates (Kim et al. 2007; Mavromatis et al. 2012). In addition, due to dissolved cation-anion pair formation, the free ion concentration can deviate substantially from the total ion concentration, especially at high solute concentration. This also depends on the dominant anion present in water, e.g. carbonate-dominant water versus chloride/ sulphate-dominant waters. Ito and Forester (2009) suggested that these complications might explain unexpected values for $\mathrm{Mg} / \mathrm{Ca}, \mathrm{Sr} / \mathrm{Ca}$, or other metal ratios for ostracod valves, i.e. values different than those predicted 
on the basis of distribution coefficients determined empirically. While the majority of the studies on ostracod oxygen isotope fractionation were carried out on bicarbonate-dominant water, host waters for $A$. robusta (Chivas et al. 2002) and for $C$. torosa (MarcoBarba et al. 2012) have a chemical composition similar to the conservative elemental ratios of seawater, chloride and sulphate being the dominant anions. It is interesting to note that the decrease in the difference between $\delta^{18} \mathrm{O}_{\text {ostra }}$ and $\delta^{18} \mathrm{O}_{\text {calcite }}$ with increasing salinity of water is less pronounced than for the species having calcified in bicarbonate-dominant waters. This suggests that the type of water might also be an important parameter influencing the oxygen isotope composition of ostracod valves.

Other factors, such as alkalinity of water or calcite saturation state, may also influence oxygen isotope fractionation. However, lack of data on host water ionic composition for the different studies precludes further detailed examination. In addition, salinity, alkalinity, $\mathrm{Mg} / \mathrm{Ca}$, and calcite saturation state are often correlated because these parameters increase in parallel for a natural change imposed on the chemical composition of the water (continental alteration, mineral dissolution, evaporation, etc.), making it difficult to assess which one of these parameters is actually responsible for the observed change in oxygen isotope fractionation. Further studies such as natural or laboratory cultures done under strictly controlled conditions are needed to better understand the potential influence of varying environmental conditions on ostracod valves and their oxygen isotope compositions.

Acknowledgments The authors would like to thank Javier Marco-Barba and Emi Ito for thorough and useful reviews of our manuscript.

\section{References}

Chivas AR, De Deckker P, Wang SX, Cali JA (2002) Oxygenisotope systematics in the nektic ostracod Australocypris robusta. In: Holmes JA, Chivas AR (eds) The OstracodaApplications in Quaternary Research. American Geophysical Union, Washington DC, Geophysical Monograph 131, pp 301-313

Davis JK, Dove PM, De Yoreo JJ (2000) The role of $\mathrm{Mg}^{2+}$ as an impurity in calcite growth. Science 290:1134-1137

Decrouy L, Vennemann TW, Ariztegui D (2011) Controls on ostracod valve geochemistry: part 2. carbon and oxygen isotope compositions. Geochim Cosmochim Acta 75: 7380-7399
Dettman DL, Smith AJ, Rea DKR, Moore TC, Lohmann K (1995) Glacial meltwater in Lake Huron during early postglacial time as inferred from single-valve analysis of oxygen isotopes in ostracodes. Quat Res 43:297-310

Friedman I, O'Neil JR (1977) Compilation of stable isotope fractionation factors of geochemical interest. In: Friedman I, O'Neil JR (eds) Data of Geochemistry. US Geological Survey, Washington DC, pp KK1-KK12

Fritz P, Anderson TW, Lewis CFM (1975) Late-quaternary climatic trends and history of Lake Erie from stable isotope studies. Science 190:267-269

Heaton THE, Holmes JA, Bridgwater ND (1995) Carbon and oxygen isotope variations among lacustrine ostracods: implications for palaeoclimatic studies. Holocene 5:428-434

Ito E, Forester RM (2009) Changes in continental ostracod shell chemistry; uncertainty of cause. Hydrobiologia 620:1-15

Keatings KW, Heaton THE, Holmes JA (2002) Carbon and oxygen isotope fractionation in non-marine ostracods: results from a 'natural culture' environment. Geochim Cosmochim Acta 66:1701-1711

Kim S-T, O’Neil JR (1997) Equilibrium and nonequilibrium oxygen isotope effects in synthetic carbonates. Geochim Cosmochim Acta 61:3461-3475

Kim S-T, O’Neil JR, Hillaire-Marcel C, Mucci A (2007) Oxygen isotope fractionation between synthetic aragonite and water: influence of temperature and $\mathrm{Mg}^{2+}$ concentration. Geochim Cosmochim Acta 71:4704-4715

Li X, Liu W (2010) Oxygen isotope fractionation in the ostracod Eucypris mareotica: results from a culture experiment and implications for paleoclimate reconstruction. J Paleolimnol 43:111-120

Li H-C, Stott LD, Hammond EH (1997) Temperature and salinity effects on ${ }^{18} \mathrm{O}$ fractionation for rapidly precipitated carbonates: laboratory experiments with alkaline lake water. Episodes 20:193-198

Marco-Barba J, Ito E, Carbonell E, Mesquita-Joanes F (2012) Empirical calibration of shell chemistry of Cyprideis torosa (Jones, 1850) (Crustacea: Ostracoda). Geochim Cosmochim Acta 93:143-163

Mavromatis V, Schmidt M, Botz R, Comas-Bru L, Oelkers EH (2012) Experimental quantification of the effect of $\mathrm{Mg}$ on calcite aqueous oxygen isotope fractionation. Chem Geol 310-311:97-105

von Grafenstein U, Erlenkeuser H, Trimborn P (1999) Oxygen and carbon isotopes in modern fresh-water ostracod valves: assessing vital offsets and autecological effects of interest for palaeoclimate studies. Palaeogeogr Paleoclimatol Palaeoecol 148:133-152

Wetterich S, Schirrmeister L, Meyer H, Viehberg FA, Mackensen A (2008) Artic freshwater ostracods form modern periglacial environments in the Lena River delta (Siberian Artic, Russia): geochemical applications for palaeoenvironmental reconstructions. J Paleolimnol 39:427-449

Xia J, Ito E, Engstrom DR (1997) Geochemistry of ostracod calcite: part 1. An experimental determination of oxygen isotope fractionation. Geochim Cosmochim Acta 60:377-382

Xu H, Hou Z, An Z, Liu X, Dong J (2010) Major ion chemistry in Lake Qinghai catchments, NE Qinghai-Tibet plateau, China. Quat Int 212:35-43 